\title{
Analysis of correlation between land surface and selected palaeosurface illustrated with examples from Central Poland
}

\section{Analiza współkształtności powierzchni terenu i wybranej paleopowierzchni na przykładach z Polski Środkowej}

\begin{abstract}
:
The article presents examples of correlation analysis between palaeosurfaces and the contemporary surface, prepared on the basis of commonly available GIS (Geographic Information Systems) tools. The study area is Central Poland, where, despite several dozen years of palaeogeographic research, no uniform view on the evaluation of the role played by the older bedrock in the genesis of contemporary relief has been formulated. The main part of the study is presentation and analysis of research procedures conducted in GIS techniques, aimed at solving the problem identified above.

Key words: $\quad$ terrain profiles, palaeosurface, GIS analyses.

Zarys treści: $\quad$ W artykule zaprezentowano przykłady analizy współzależności między powierzchniami kopalnymi (paleopowierzchniami) i powierzchnią współczesną, opracowane w oparciu o powszechnie dostępne narzędzia z rodziny GIS (Geograficzne Systemy Informacyjne). Jako obszar badań wybrano Polskę Środkową, gdzie pomimo kilkudziesięciu lat badań paleogeograficznych, nie ukształtowała się jednoznaczna opinia co do oceny roli starszego podłoża w pochodzeniu rzeźby współczesnej. Główną część opracowania stanowi przedstawienie oraz analiza procedur badawczych prowadzonych w technikach GIS mających na celu rozwiązanie wskazanego wyżej problemu.
\end{abstract}

Słowa kluczowe: profile terenu, powierzchnia kopalna, analizy GIS.

\section{Introduction}

While conducting palaeogeographic research, one of the stages of work is to analyse the relations between the sub-Quaternary and contemporary surfaces. Frequently, owing to the character of these studies, correlation analyses are performed by visual comparison of the contour lines of two maps or by analysing juxtaposed profiles or geological cross-sections. In the author's opinion, this method is fairly subjective - particularly when we want to compare data from different areas. This work presents an idea for fast comparison of sub-Quaternary and contemporary profile lines illustrated with examples from Central Poland. According to the author, this method allows for making a simple evaluation of correlation between various surfaces along selected lines, with the use of basic GIS (Geographic Information Systems) tools, without the need to learn advanced statistical methodology. However, it must be stressed that the presented procedural scheme is just one of many paths to solving the analysed problem.

\section{Location and palaeogeography of the study area}

The area under analysis is located in Central Poland (fig. 1). It constitutes a transitional zone between the geophysical provinces of the Central European Lowland and the Polish Uplands (Kondracki 1968, 1998).

The most important stages of geological development of the analysed area date back to the Permian, when the Danish-Polish Furrow began to form (Pożaryski 1964, 1974). Later, in the periods of the Mesozoic, the area witnessed numerous marine transgressions and regressions. The Zechstein-Mesozoic complex, originated at that time, is characterised by very high thickness of rocks, often reaching up to 10 thousand metres. Changes occurring within this complex, forming its current shape, were mainly caused by vertical movements of the bedrock (Dadlez, Marek 1969, 1974, 1977).

Forming of the relief of the Quaternary base in the analysed area started in the Laramian phase of the Alpine orogeny. Marine floods receded ultimately at the turn of the Miocene and the Pliocene. At that time, the land formed a single, undivided whole with the Scandinavia (Różycki 1967, 1972). A large freshwater reservoir was formed then. Intense denudation, whose material filled depressions, occurred in areas outside of the reservoir. The reservoir was fed mostly from the area of Southern Poland, along with its uplands, and from the area of contemporary Pomerania and the Eastern-European platform.

In the Quaternary, the analysed area underwent several Pleistocene glaciations, of which the Wartanian glaciation was of particular morphogenetic significance (Turkowska 2006; Rdzany 2009). The most important processes which shaped the Neogenic surface include: block tectonic movements, saline tectonics, glacigenic, glacifluvial and periglacial processes, as well as erosion and denudation during interglacial periods.

Numerous marine and lacustrine transgressions, later overlapping geological processes operating in the Quaternary, and the location of the area resulted in the structural duality of the sub-Quaternary surface (Turkowska 2006), which means that it can be divided into vast areas of exposed Mesozoic sediments and covers of sediments from the Palaeogene and Neogene. Mesozoic sediments are most frequently represented by solid rocks: marls, limestones and sandstones, although near Tomaszów Mazowiecki 


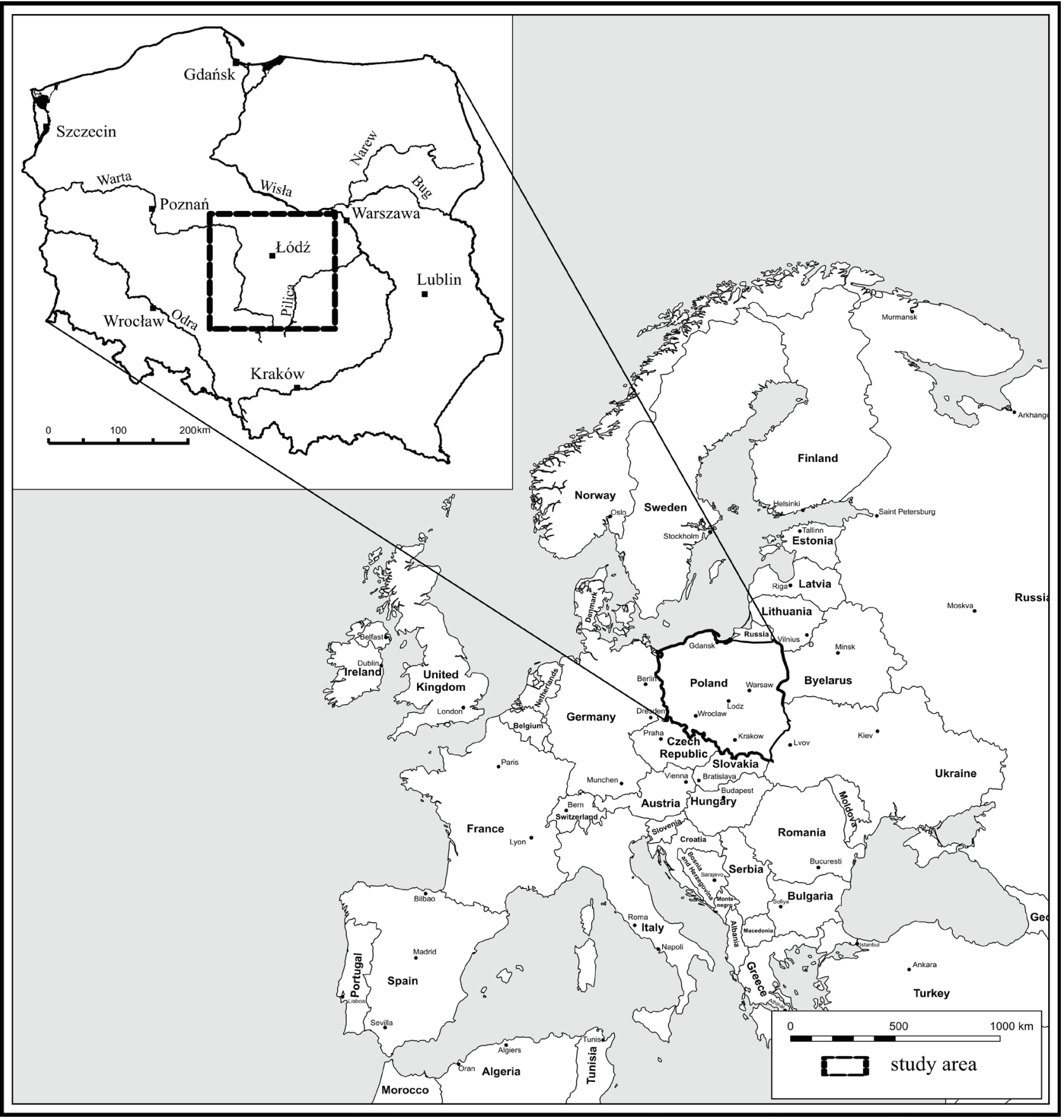

Fig. 1. Location of the analysed area with reference to Poland and Europe

Rys. 1. Położenie obszaru badań na tle Polski i Europy

they are represented by Cretaceous sands whose characteristics - as loose sediments - are close to the Quaternary ones.

Sediments of the Palaeogene are mostly represented by glauconitic sands of the Eocene and Oligocene sea. Additionally, silts, shales and brown coals occur here, with thickness of up to several dozen metres in tectonic depressions. With a significant degree of data simplification, it can be assumed that the presented sediments of the Jurassic and Cretaceous age are solid, whereas those of the Palaeogene and Neogene - loose and plastic. Sediments of the Quaternary age are represented mainly by boulder tills, glacifluvial sands and gravels, fine marginal lake sediments, eolian and fluvial sands.
In the analysis of relations between the older bedrock and the contemporary relief in Central Poland, the following dependencies are most frequently indicated:

1. Relations between the shaping of Quaternary bedrock surface macroforms and the contemporary surface (Galon 1970).

2. Relations between the layout of the valley network upon the Quaternary bedrock and the contemporary surface (Krzemiński 1965; Klatkowa 1972; Baraniecka 1975; Sadłowska 1982; Forysiak 2004; Twardy 2004; Turkowska 2006).

3. Relations between the disjunctive tectonics and the distribution of Quaternary forms and sediments (Galon 1970; Klajnert 1978; Rdzany 1996, 1997; Molewski 2007). 
In this work, references have been made to the issues in question in the macroscale, with focus on the analysis of correlation between inclination of the hypothetical palaeosurface and the contemporary surface on the basis of juxtaposed latitudinal profile lines.

\section{Research methodology}

Two source layers were analysed. For the Quaternary surface, data from Geological maps of Poland without the Quaternary formations in the scale 1:200 000 was used. The analysed area is covered by 9 sheets of these maps: Konin (Ciuk 1979), Płock (Baraniecka, Skompski 1988), Warszawa-Zachód (Słowański et al. 1995), Kalisz (Baranowski, Mańkowska 1972), Łódź (Piwocki 1980), Skierniewice (Makowska 1972), Kluczbork (Haisig et al. 1979), Częstochowa (Haisig, Biernat 1980), Kielce (Filonowicz 1978). For analysis of the contemporary surface, Digital Elevation Model was used with grid interval of at least 100 metres, made available by CODGiK (Main Centre of Geodetic and Cartographic Documentation). Preparatory work, such as data digitalisation and interpolation, was performed with the use of Surfer 8 and 12 software. Data processing and analyses were performed in the SAGA GIS, Quantum GIS, Microsoft Excel and ArcGIS 10.2 software. Final graphical work was prepared using the Corel Draw X5 software. The course of research works was divided into several stages: data collection, processing and analysis. Depending on the kind of source materials, some research stages can be skipped. Due to the character of this study, a detailed description of individual procedures performed in the GIS software was presented in the main part of the text.

\section{Stage I. Data collection}

A system of spatial references (georeferencing) was imposed onto scanned maps in the Quantum GIS 1.6 software, with the Georeferencer tool, using linear transformation. For manual digitalisation of contour lines from geological maps, the Surfer 8 software was used.

The Digital Elevation Model (CODGiK) with grid interval of at least $100 \mathrm{~m}$, is a generalised image of data from the LPIS project (Land Parcel Identification System). It is available in the form of an X, Y, Z table (rectangular coordinates with terrain ordinate in the National Geodetic Coordinate System 1992 - PUWG1992), divided into voivodeships. In order to obtain consistent elevation data for the analysed area (fig. 1), it was necessary to merge elevation data from seven voivodeships. This operation can be performed in two ways, i.e. by copying data for individual voivodeships to a single file or by automatic merging in a dedicated application. In the former case, for such a large area, you need software which will efficiently deal with millions of rows in a spreadsheet (processing speed, memory addressing by the operational system). The second method is much faster, though it requires possible removal of the $X, Y, Z$ headers from the files. For the purposes of this study, the TXTcollector 2 software was used. The obtained merged file containing the elevation data was imported into the SAGA GIS software using the Import Grid from $X Y Z$ function from the Import/Export - Grids tool group. When importing data, attention must be paid to the horizontal resolution of the grid ( $100 \mathrm{~m}$ in this case), method of separating cells in the txt file (space in the case of CODGiK data) and whether the txt file contains field names (fields in databases or column headers in spreadsheets). Data imported in this way can be processed in the SAGA GIS software or exported to another desirable data format, e.g. using functions from the Import/Export - Grids tool group. In this case, data was converted to the GDR format by Golden Software.

In order to be able to compare two surfaces using the method described below, it is important to apply data grids with the same spatial range and vertical resolution. The previously obtained digital model of the contemporary surface must be clipped to the required spatial range. The clipping mask, created in ArcGIS 10.2, was a quadrangle with the following coordinates: $18^{\circ} 03^{\prime} \mathrm{E}$ to $20^{\circ} 41^{\prime} \mathrm{E}$ and $50^{\circ} 50^{\prime} \mathrm{N}$ to $52^{\circ} 53^{\prime} \mathrm{N}$, converted to the PUWG1992 rectangular coordinate system. The clipping operation was performed in the Spatial Analyst Tools / Extraction / Extract by Mask module, and the resulting file was saved in the GRID format. The same operation can be performed in the SAGA GIS program, using the Shapes - Grid / Clip Grid with Polygon tool.

The second layer, corresponding to the sub-Quaternary surface, was obtained as a result of digitising the morphometric content of the geological maps, and then interpolating using the natural neighbour method with grid interval of 100 metres, using the Surfer 12 program (Badura, Przybylski 2005; Kowalczyk 2009). The resulting file, as was the case for the contemporary surface, should be saved in the same coordinate system as the contemporary surface layer (PUWG1992), and then clipped using the same mask.

\section{Stage II. Correcting elevation data between input layers}

The input data coming from different sources and obtained using different methods is very likely to be of different vertical precision (Hejmanowska et al. 2008). For the geological maps used in this study, depending on terrain denivelation within the given sheet, the contour interval is 10 or 20 metres. The vertical resolution of the Digital Elevation Model (CODGiK) is below $1 \mathrm{~m}$. Theoretically, ordinates of the palaeosurface should not exceed the ordinate values of the contemporary surface at the same locations. After comparing both sets of data, it appears that discrepancies occur in many places. Most probably, they occur for two reasons: different accuracy of the input data and anthropogenic changes of the land surface. In the former case, it is necessary to account for the grid interval of the geological maps and the vertical precision of the DEM. For instance, if the elevation of a measured point in the outcrop zone of the older surface is 147.5 m.a.s.l., then it will be found within the 150 m.a.s.l. contour line in the contour drawing with $10 \mathrm{~m}$ contour interval. After comparing it with data for the contemporary surface, it will appear that the old relief was 2.5 metres higher than the contemporary one. Other sources of discrepancies, though with a narrower scope, may include the time of preparing the map and the operation of the mining industry at some locations. At the moment of taking the measurements, an unmined hill might have been elevated higher than now.

In order to eliminate the discrepancies, their locations must be determined and appropriate corrections must be made. Corrections were introduced in the tabular data, coming from source bitmaps. In this data correction method, it is important for both analysed layers to have the 
same horizontal resolution and extent. This information may be obtained from GIS applications by displaying the GRID data. Depending on the origin of the elevation data (different interpolation methods), the analysed grids are very likely to differ. One possible solution is to re-interpolate data using the same method. Both input layers obtained in the previous stages were exported in Surfer 12 to the $X Y Z$ tabular form (dat file), and then rows that contained errors or no elevation data were found and removed using the sorting function. While working, you should check whether column headers have signatures and what symbol is used to divide individual cells. Data prepared in this way was re-interpolated using identical spatial ranges and resolution for both sets. Owing to the extent of the analysed area, the grid interval of 250 metres was used. After this operation, the GRD grids were exported to tabular form. As a result of the above actions, tables with data for both surfaces had the same number of rows. The data was then imported into an MS Excel 2013 spreadsheet. For easier sorting of data, another column was added, containing ordinal numbers, and the decimal mark was changed from point to comma. Subsequently, error values were removed by sorting both sets of data by elevation. In order to find bitmap cells whose palaeosurface was elevated higher than the contemporary one, the palaeosurface elevation value was subtracted from the contemporary one. The resulting thickness values were not supposed to be negative. For isolating such locations, data was re-sorted by thickness, and rows containing negative values were removed. While correcting elevation data on maps of the sub-Quaternary bedrock, the occurrence of outcrops should be accounted for. A question arises whether they should be treated literally as outcrops - older bedrock exposed directly on the land surface, or interpreted as it is frequently practiced in geological cartography, where places with the Quaternary cover not exceeding 1 metre are treated as outcrops of older surface. For the purposes of this study, all locations with the Quaternary cover thickness lower than $0.5 \mathrm{~m}$ were rejected. The final part of this stage was to re-interpolate the data using the same input parameters as before.

Stage III. Reading of surface ordinate values along profile lines from Digital Elevation Models.

Tabular data makes it possible to perform correlation analyses of their shape. Taking into account the complexity of geological and geomorphological processes, it seems more appropriate to perform analysis along specific delimitations, such as e.g. tectonic units or morpholineaments. For the Łódź Region, it may be assumed that the relation between the bedrock and the contemporary surface should increase southwards, towards the Polish Uplands. In order to verify the hypothesis, a linear grid with the horizontal interval of $5 \mathrm{~km}$ was generated on the basis of the quadrangle which delimited the analysed area in SAGA GIS, using the Shapes - Tools / Create graticule function (in Quantum GIS: Tools/Research Tools/Vector grid). Then, using the Import/Export - Grids / Import Surfer Grid function, DEMs obtained at previous stages of the works were loaded into the program. Values along the profile lines were read using the Terrain Analysis - Profiles / Profiles from Lines function. The point layer was exported from the DATA tab to the SHP format.

Stage IV. Analysis of correlation between profile lines of different surfaces.

The SHP vector layers, which were obtained at the previous stage, can either be analysed directly in GIS applications or the information can be read from the table of layer attributes and then calculated in a spreadsheet. As it was necessary to prepare a cartographic presentation in GoldenSoftware Grapher 5, again the calculations were made in a spreadsheet. For this, data from .dbf files, which are a component of the shp layer, were copied to the spreadsheet and later divided according to the identification number of each profile line. As it was pointed out in the introduction to this article, one of the goals of the study was to apply a simple analytical tool for determining the possible correlation between the shape of various palaeogeographic surfaces. In order to achieve this goal, it was decided to use the Pearson linear correlation function. Results obtained in the spreadsheet for individual profile lines were introduced to the layer along with their location (fig. 2).

\section{Evaluation of research results}

The juxtaposed profile lines for the Quaternary and contemporary surfaces indicate a mutual relation (fig. 2). However, it must be pointed out that without a more detailed comparison of results, obtained using other methods for the same analysed area, it is difficult to determine the strength of this correlation explicitly and precisely. The same values of Pearson correlation coefficient can have different significance, depending on the analysed phenomena.

In order to evaluate the obtained results, a graphical juxtaposition was made for individual profile pairs, five of which are presented below (fig. 3). Profile 1 is located within the extent of the Vistulian glaciation. Pearson linear correlation coefficient for it is 0.69 , which, given the general interpretation of the standard, may be regarded as significant interdependence. The course of the lines shown in the drawing correspond mainly within the limits of elevations of older bedrock, whereas palaeovalleys have become obliterated. An example of an area with negative or close to zero correlation is the Warsaw-Berlin proglacial valley (fig. 2, 3, profile 10).

In this case, it is clearly visible that depressions of the palaeosurface are accompanied by elevations of the contemporary surface. Another location, where increased correlation between the shape of both analysed surfaces may be observed is the central part of the analysed area, including the peripheral zone of the Łódź Hills (fig. 2, 3, profile 15). Here, correspondences both in the shape of higher rank landforms (e.g. plateaus) and, probably, river valleys can also be observed. Certainly, increased dependence between the shape of the Quaternary and contemporary 




$-1,0$ - 1,00 - Pearson correlation coefficients p01 - profile number

Fig 2. Pearson linear correlation along the profile lines of the Quaternary bedrock and contemporary surface (digital elevation model made available by CODGiK, with grid interval of at least $100 \mathrm{~m}$, generalised to $250 \mathrm{~m}$ )

Rys. 2. Korelacja liniowa Pearsona na liniach profili powierzchni podłoża czwartorzędu oraz powierzchni współczesnej (cyfrowy model wysokościowy udostępniony przez CODGiK o interwale siatki co najmniej $100 \mathrm{~m}$, zgeneralizowany do $250 \mathrm{~m}$ )

surfaces can be expected in the zone of the Polish Uplands (fig. 2, 3, profiles 23, 31). Pearson correlation coefficient values, shown in the drawings, oscillate around 0.9 , which indicates nearly strict correlation. Profile analysis confirms the conclusions, though it must be kept in mind that in these areas the older bedrock is at the same time the contemporary surface. However, this study is not aimed at attempting to explain the causes of the observed possible interdependencies - it is a separate topic for broad research.
Juxtaposition of example profiles along the analysed surfaces and the calculated Pearson correlation coefficient values indicate this standard to be useful in palaeogeographic studies. Some reservations can be raised by the quantitative determination of the correlation, but it is certainly possible to compare two different areas qualitatively. As it was mentioned before, it is just one of many ways to achieving goals set for this study, though, in the author's opinion, it is feasible on the basis of simple analytical tools. 
m.a.s.l.

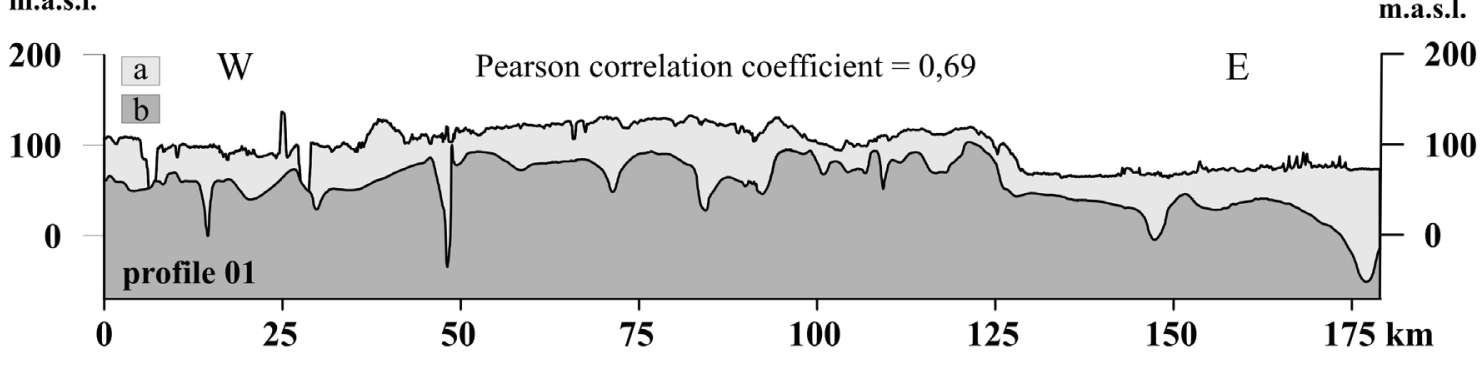

m.a.s.l.

.a.s.l.

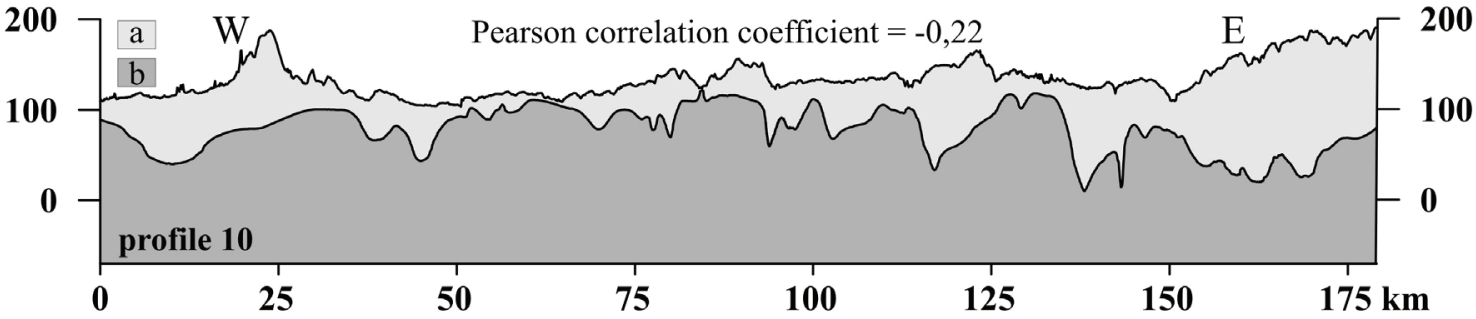

m.a.s.l.
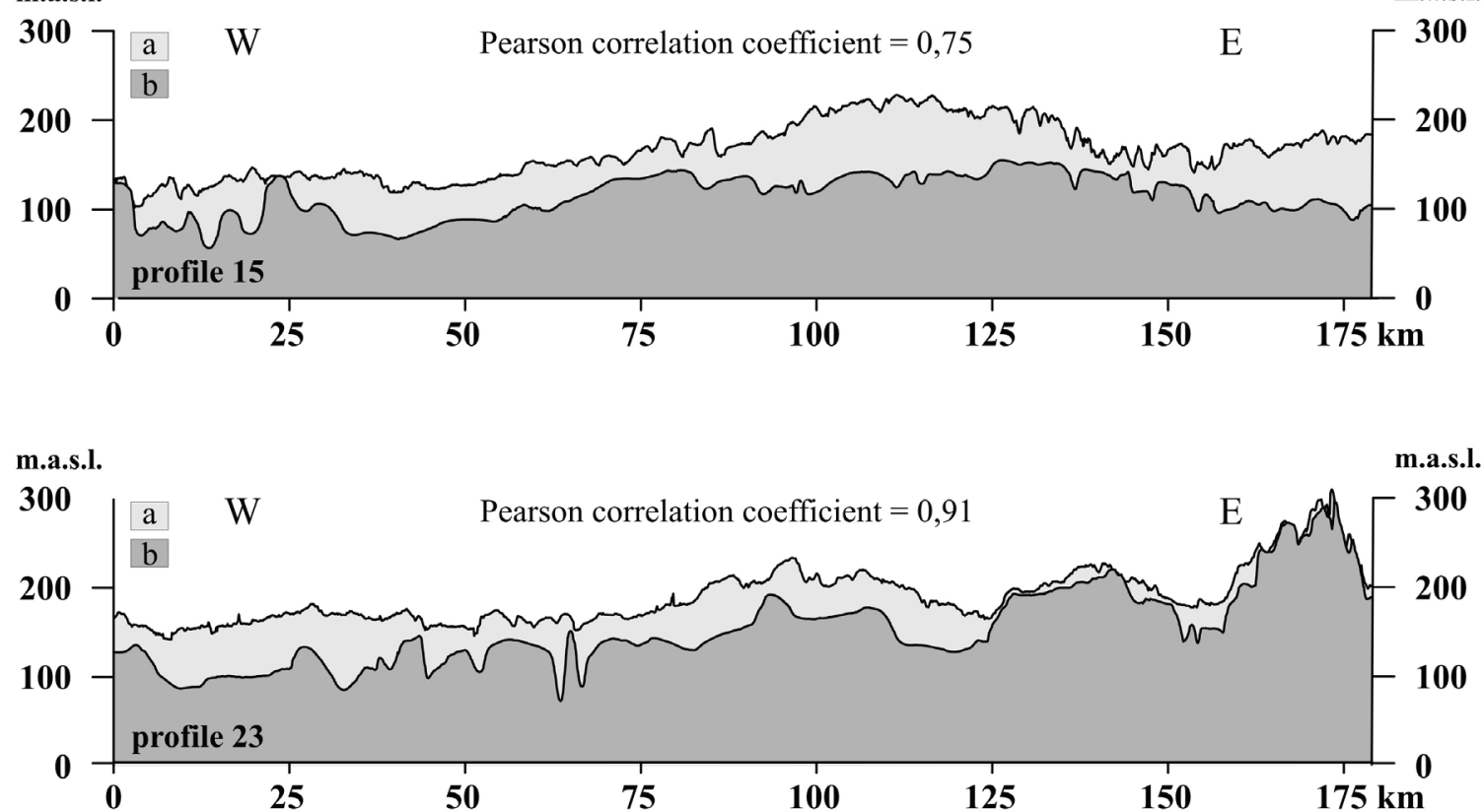

m.a.s.l.

m.a.s.l.

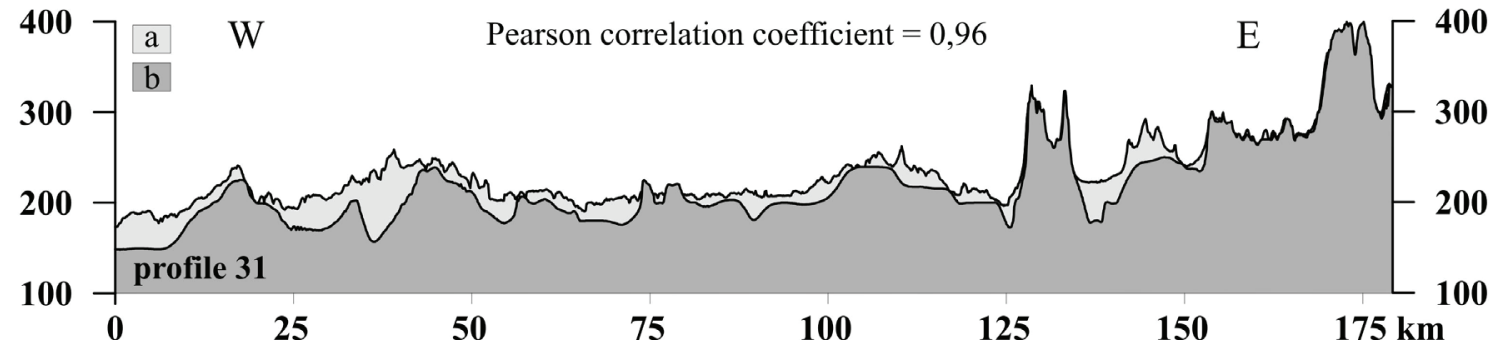

Fig. 3. Juxtaposition of example profiles along the contemporary surface (a) and the sub-Quaternary one (b)

Rys. 3. Zestawienie przykładowych profili wzdłuż powierzchni współczesnej (a) oraz podczwartorzędowej (b) 


\section{References}

Badura, J., Przybylski, B., 2005. Application of digital elevation models to geological and geomorphological studies - some examples. Przegląd Geologiczny 53 (10/2), 977-983.

Baraniecka, M.D., 1975. Zależność wykształcenia osadów czwartorzędowych od struktur i dynamiki podłoża w środkowej części Niżu Polskiego. Biuletyn Instytutu Geologicznego 288 (16), 5-97.

Baraniecka, M.D., Skompski, S., 1988. Mapa geologiczna Polski w skali 1:200 000 ark. Płock, wyd. B, Mapa geologiczna odkryta bez utworów czwartorzędowych. PIG, Warszawa.

Baranowski, J., Mańkowska, A., 1972. Mapa geologiczna Polski w skali 1:200 000 ark. Kalisz, wyd. B, Mapa geologiczna odkryta bez utworów czwartorzędowych. PIG, Warszawa.

Ciuk, E., 1979. Mapa geologiczna Polski w skali 1:200 000 ark. Konin, wyd. B, Mapa geologiczna odkryta bez utworów czwartorzędowych. PIG, Warszawa.

Dadlez, R., Marek, S., 1969. Styl strukturalny kompleksu cechsztyńsko-mezozoicznego na niektórych obszarach Niżu Polskiego. Kwartalnik Geologiczny 13 (3), 543-565.

Dadlez, R., Marek, S., 1974. Polska północno-zachodnia i środkowa, [w: Budowa geologiczna Polski, t. 4, Tektonika, cz. 1, Niż Polski. Wyd. Geol., Warszawa, 239-255.

Dadlez, R., Marek, S., 1977. Tektonika, [w:] Marek S. (red.), Budowa geologiczna wschodniej części niecki mogileńsko-łódzkiej (strefa-Gopło-Ponętów-Pabianice). Prace Instytutu Geologicznego 80, 121-127.

Filonowicz, P., 1978. Mapa geologiczna Polski w skali 1:200 000 ark. Kielce, wyd. B, Mapa geologiczna odkryta, bez utworów czwartorzędowych. PIG, Warszawa.

Forysiak, J., 2004. Wpływ podłoża mezozoicznego na morfologię i przebieg doliny Warty między Burzeninem i Dobrowem, [w:] III. Świętokrzyskie spotkania geologiczno-geomorfologiczne nt. Rzeźba i osady czwartorzędowe na tle struktur starszego podłoża obszaru Polski, „Jodłowy Dwór” pod Świętym Krzyżem, 13-15.05.2004 r., Kielce, 22-23.

Galon, R., 1970. Uwagi o wpływie konfiguracji i struktury podłoża plejstocenu na rozwój sieci dolinnej Polskiego Niżu. Acta Geographica Lodziensia 24

Haisig, J., Biernat, S., 1980. Mapa geologiczna Polski w skali 1:200 000 ark. Częstochowa, wyd. B, Mapa geologiczna odkryta bez utworów czwartorzędowych. PIG, Warszawa.

Haisig, J., Wilanowski, J., Biernat, S., Kaziuk, H., Kotlicki, S., 1979. Mapa geologiczna Polski w skali 1:200 000 ark. Kluczbork, wyd. B, Mapa geologiczna odkryta bez utworów czwartorzędowych. PIG, Warszawa.

Hejmanowska, B., Drzewiecki, W., Kulesza, Ł., 2008. Zagadnienie jakości numerycznych modeli terenu. Archiwum Fotogrametrii, Kartografii i Teledetekcji 18, 163-175.

Klajnert, Z., 1978. Zanik lodowca warciańskiego na Wysoczyźnie Skierniewickiej i jej północnym przedpolu. Acta Geographica Lodziensia 38, $1-149$.
Klatkowa, H., 1972. Paleogeografia Wyżyny Łódzkiej i obszarów sąsiednich podczas zlodowacenia warciańskiego. Acta Geographica Lodziensia 28, 1-220.

Kondracki, J., 1968. Fizycznogeograficzna regionalizacja Polski i krajów sąsiednich w systemie dziesiętnym. Prace Geograficzne IG PAN 69, 13-69.

Kondracki, J., 1998. Geografia regionalna Polski. PWN, Warszawa.

Kowalczyk, K., 2009. Interpolacja ruchów pionowych skorupy ziemskiej z użyciem programu Surfer 8. Geodeta 8 (171) sierpień 2009.

Krzemiński T., 1965. Przełom doliny Warty przez Wyżynę Wieluńską. Acta Geographica Lodziensia 21, 1-95

Makowska, A., 1972. Mapa geologiczna Polski w skali 1:200 000 ark. Skierniewice, wyd. B, Mapa geologiczna odkryta bez utworów czwartorzędowych. PIG, Warszawa.

Molewski, P., 2007. Geotektoniczne i glacidynamiczne uwarunkowania wykształcenia plejstocenu Wysoczyzny Kujawskiej. Wydawnictwo Naukowe Uniwersytetu Mikołaja Kopernika, Toruń, 1-40.

Piwocki, M., 1980. Mapa geologiczna Polski w skali 1:200 000 ark. Łódź, wyd. B Mapa geologiczna odkryta bez utworów czwartorzędowych. PIG, Warszawa.

Pożaryski, W., 1964. Zarys tektoniki paleozoiku i mezozoiku Niżu Polskiego. Kwartalnik Geologiczny 2, 1-32.

Pożaryski, W., 1974. Tektonika, część | - Niż Polski, [w:] Budowa geologiczna Polski, t. IV. Państ. Inst. Geol. Warszawa, 13-34, 239-314.

Rdzany, Z., 1996. Wpływ rzeźby podłoża lądolodu warciańskiego na przestrzenny rozkład skutków deglacjacji i późniejsze przekształcenia rzeźby w okolicach Rawy Mazowieckiej. Acta Geographica Lodziensia 71, 193-205.

Rdzany, Z., 1997. Kształtowanie rzeźby terenu między górną Rawką a Pilicą w czasie zaniku lądolodu warciańskiego. Acta Geographica Lodziensia 73, 1-146.

Rdzany, Z., 2009. Rekonstrukcja przebiegu zlodowacenia warty w regionie łódzkim. Wydawnictwo Uniwersytetu Łódzkiego, 1-310.

Różycki, S.Z., 1967. Plejstocen Polski Środkowej na tle przeszłości w górnym trzeciorzędzie. PWN, Warszawa, 1-236.

Różycki, S.Z., 1972. Plejstocen Polski Środkowej na tle przeszłości w górnym trzeciorzędzie. PWN, Warszawa, 1-316.

Sadłowska, A., 1982. Rozwój rzeźby międzyrzecza Pilicy, Czarnej i Drzewiczki. Acta Geographica Lodziensia 47, 1-108.

Słowański W., Piechulska-Słowańska, B., Gogołek, W., 1995. Mapa geologiczna Polski w skali 1:200 000 ark. Warszawa-Zachód. Polska Agencja Ekologiczna.

Turkowska, K., 2006. Geomorfologia regionu łódzkiego. Wydawnictwo Uniwersytetu Łódzkiego, Łódź, 1-238.

Twardy, J., 2004. Odzwierciedlenie dynamiki podłoża mezozoicznego w morfologii i budowie geologicznej doliny Neru w okolicach Lutomierska (Wysoczyzna Łaska), [w:] Sołtysik R. (red.), Czwartorzęd obszaru Polski na tle struktur starszego podłoża. Prace Instytutu Geografii Akademii Świętokrzyskiej w Kielcach 13, 107-124. 